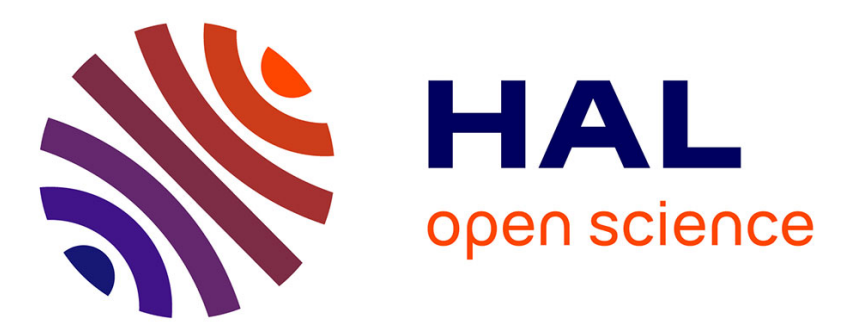

\title{
Production of Innervated Skeletal Muscle Fibers Using Human Induced Pluripotent Stem Cells
}

Mégane Delourme, Natacha Broucqsault, Kilian Mazaleyrat, Frédérique

Magdinier

\section{- To cite this version:}

Mégane Delourme, Natacha Broucqsault, Kilian Mazaleyrat, Frédérique Magdinier. Production of Innervated Skeletal Muscle Fibers Using Human Induced Pluripotent Stem Cells. Methods in Molecular Biology, 2020, 10.1007/7651_2020_334. hal-03142891

\section{HAL Id: hal-03142891 \\ https: / hal-amu.archives-ouvertes.fr/hal-03142891}

Submitted on 12 Mar 2021

HAL is a multi-disciplinary open access archive for the deposit and dissemination of scientific research documents, whether they are published or not. The documents may come from teaching and research institutions in France or abroad, or from public or private research centers.
L'archive ouverte pluridisciplinaire HAL, est destinée au dépôt et à la diffusion de documents scientifiques de niveau recherche, publiés ou non, émanant des établissements d'enseignement et de recherche français ou étrangers, des laboratoires publics ou privés. 


\title{
Production of Innervated Skeletal Muscle Fibers Using Human Induced Pluripotent Stem Cells
}

\author{
Mégane Delourme, Natacha Broucqsault, Kilian Mazaleyrat, \\ and Frédérique Magdinier
}

\begin{abstract}
Only a limited number of large-scale protocols describe the production of mature skeletal muscle fibers from human induced pluripotent stem cells (hiPSCs). Here we describe a novel procedure for simultaneous differentiation of hiPSC into muscle cells and motor neurons, that generates innervated and contractile multinucleated skeletal muscle fibers with sarcomeric organization. Our protocol permits the production of expandable skeletal muscle progenitor cells and mature skeletal muscle fibers that can be used for the exploration of skeletal muscle differentiation for basic research, disease modeling, and drug discovery.
\end{abstract}

Key words Stem cells, Myoblasts, Myotubes, Motor neurons, Muscle fiber, Contraction, Sarcomere, Neuromuscular junction, Neuromuscular disease modeling

\section{Introduction}

Thanks to their endless renewal and differentiation capacities into all cell type, induced pluripotent stem cells obtained after reprogramming of primary somatic cells have revolutionized the cell biology and disease modeling fields and provided an invaluable source of materials to improve our understanding of disease pathogenesis, and for designing and testing new therapeutics, including cell therapy [1-4]. Exposing human iPSCs (hiPSCs) to a combination of factors that mimic developmental cues favors the commitment toward specific differentiation pathways and the production of cellular progenies corresponding to the three embryonic layers, that is, endoderm, mesoderm, or ectoderm and subsequent derivatives. For a large number of lineages or cell types, protocols are well established but, in some cases, challenges remain and experimental developments or optimization are still required in order to reduce the cost and timing of the process and obtain large amount of wellcharacterized differentiated cells. 
One of the best examples is the skeletal muscle differentiation pathway for which reproducible methods remain sparse. Indeed, while skeletal muscle cells can be derived from mouse ES or iPS cells [5-7], only a limited number of studies report an efficient direct derivation of muscle cells from human ES and iPSCs [8,9] for production of mature skeletal muscle fibers that express adult myosin isoform and showing sarcomeric organization. As a consequence, modeling of neuromuscular disorder has been lagging behind compared to other groups of diseases.

To achieve skeletal muscle differentiation and production of innervated muscle fibers from hiPSCs, we set up a five-step procedure (Fig. 1), each step corresponding to the sequential addition or removal of small molecules in a precise order. This serum-free protocol stems from the dual modulation of the Wnt and BMP pathways that induce paraxial development $[10,11]$ but incorporates inhibition of the Notch pathway which increases myogenic specification $[12,13]$, and facilitates production of motor neurons as well as muscle maturation.

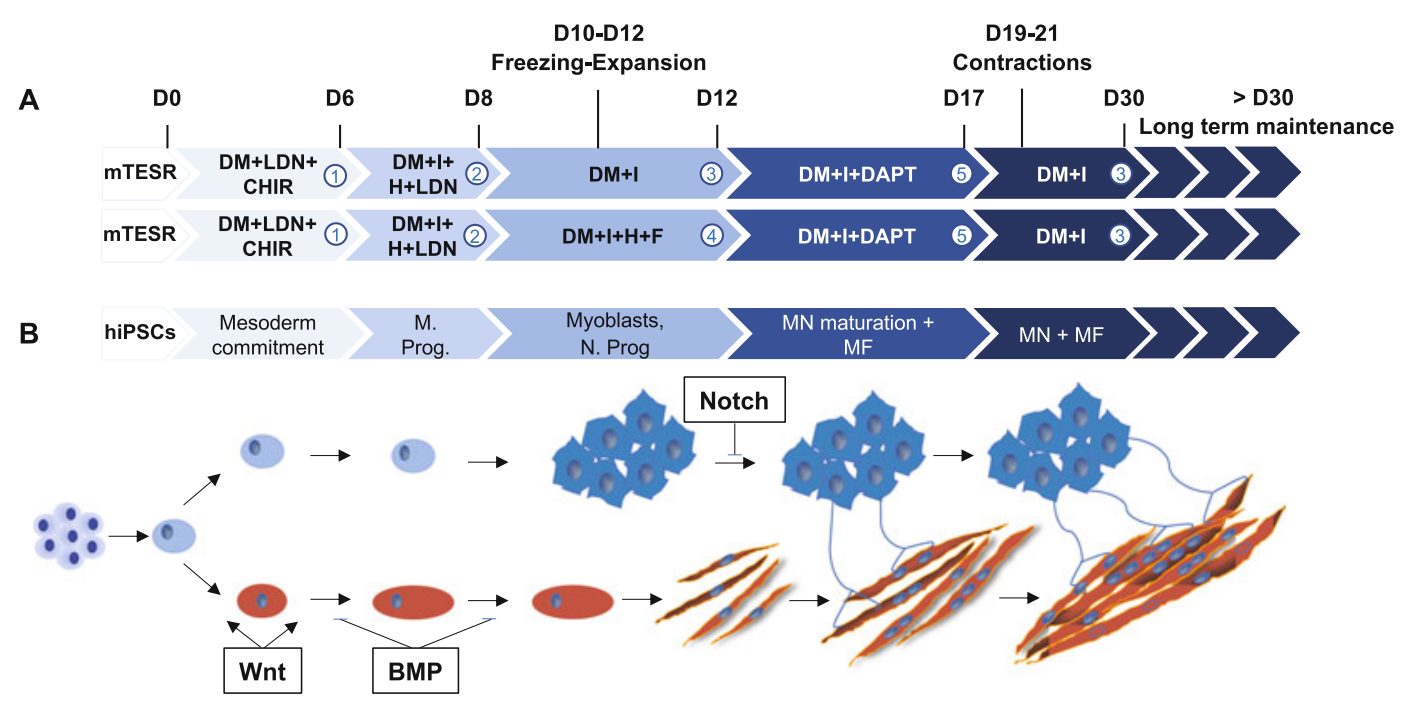

Fig. 1 Protocol for myogenic differentiation. (a) Timeline and differentiation steps for production of innervated muscle fibers from human induced pluripotent stem cells (hiPSCs) from Day 0 (D0) corresponding to the plating of hiPSCs on Matrigel-coated dishes to D30 (mature innervated muscle fibers). Cells can be maintained beyond this last time point. The different intermediate time points corresponding to changes of media are indicated (D6, D8, D12, and D17). The composition of the medium is indicated for the different culture steps. CHIR: CHIR99021; LDN: LDN193189; F: FGF2; I: IGF1; H: HGF; DAPT: N-[N-(3,5-Difluorophenacetyl)-L-alanyl]S-phenylglycine t-butyl ester. Cells can be frozen between Days 10 and 12 for storage, expansion thawing and further differentiation. First contractions are visible between Day 19 and 21 postdifferentiation (upper row). When further expansion is needed, differentiation medium step 3 (Subheading 2.3.4) $(\mathrm{DM}+\mathrm{I})$ can be replaced by differentiation medium step 4 (Subheading 2.3.5) (DM + I + H + F). (b) The different steps of differentiation are indicated together with a schematic representation of the cell types observed 
From a full $35 \mathrm{~mm}$ dish, hiPSC colonies are mechanically disrupted and small clumps of cells are plated on a new Matrigelcoated $35 \mathrm{~mm}$ dish in a chemically defined differentiation medium supplemented with FGF2, LDN 193189 BMP pathway inhibitor, and CHIR 99021 GS3K inhibitor, in the presence of Thiazovivin, a Rock pathway inhibitor. After induction of differentiation, cells undergo a period of exponential growth with the appearance of neuronal and skeletal muscle progenitors at the periphery of colonies. At Day 7, cells are grown in differentiation medium supplemented with Insulin Growth Factor 1 (IGF1) and Hepatocyte Growth Factor (HGF) and LDN 193189 for 48 h to favor muscle and neuron progenitor differentiation. At Day 8, LDN 193189 and $\mathrm{HGF}$ are removed and cells are grown in the presence of IGFl to favor cell proliferation. Neuronal progenitors can be distinguished as small cells forming rosettes while muscle progenitors are large cells that rapidly align as parallel batches of cells. At Day 12, the addition of the DAPT $\gamma$ secretase and Notch pathway inhibitor favors neuronal differentiation. Cells are maintained in the presence of DAPT up to the 17th day post differentiation. Axons become visible by bright field imaging around D17. During the last differentiation step, muscle progenitors progressively fuse and form large patches of elongated multinucleated fibers visible by bright field imaging. The first fiber contractions are visible 2-4 days after the removal of DAPT (days 19-20).

The presence of both motor neurons and muscle cells favors maturation of both cell types and self-organization of cells with formation of neuromuscular junctions at the surface of muscle fibers. The presence of neuronal and muscle progenitors facilitates regeneration of the culture and maintenance of the culture on the long-term without massive cell detachment and loss of functionality. The same conditions can be used for disease modeling.

\section{Materials}

\subsection{Preparation of Small Molecules and Growth Factors}

Prepare all reagents under sterile conditions. Store cell culture media at $4{ }^{\circ} \mathrm{C}$, growth factors and small molecules at $-20{ }^{\circ} \mathrm{C}$. Diligently follow all appropriate disposal regulations when disposing of waste materials.

1. CHIR 99021: resuspend $5 \mathrm{mg}$ CHIR99021 in $1.07 \mathrm{~mL} \mathrm{DMSO}$ for a $10 \mathrm{mM}$ stock solution.

2. DAPT : (N-[(3,5-difluorophenyl)acetyl $]$-L-alanyl-2-phenyl $]$ glycine 1,1-dimethylethyl ester): resuspend $5 \mathrm{mg}$ DAPT in $1.16 \mathrm{~mL}$ DMSO for a $10 \mathrm{mM}$ stock solution.

3. FGF2: follow manufacturer's instructions for FGF2 resuspension. Classically, FGF2 is resuspended in $5 \mathrm{mM}$ Tris $\mathrm{HCl} \mathrm{pH} \mathrm{7.6.}$ Use $1 \mathrm{~mL} 0.5 \mathrm{mM}$ Tris $\mathrm{HCl} \mathrm{pH} 7.6$ to resuspend $100 \mu \mathrm{g}$ FGF2 (100 $\mathrm{g} / \mathrm{mL}$ stock solution). 


\subsection{Preparation of Matrigel-Coated Cell Dishes}

\subsection{Preparation of Cell Culture Media}

2.3.1 Basal

Differentiation Medium

2.3.2 Differentiation Medium Step 1

2.3.3 Differentiation Medium Step 2

2.3.4 Differentiation Medium Step 3
4. HGF: follow manufacturer's instructions for HGF resuspension. Classically HGF is resuspended in sterile ultrapure water. Use $1 \mathrm{~mL} \mathrm{H}_{2} \mathrm{O}$ to resuspend $100 \mu \mathrm{g} \mathrm{HGF}(100 \mu \mathrm{g} / \mathrm{mL}$ stock solution).

5. IGF1: follow manufacturer's instructions for IGF1 resuspension. IGFl: Classically IGFl is resuspended in sterile ultrapure water. Use $1 \mathrm{~mL} \mathrm{H}_{2} \mathrm{O}$ to resuspend $100 \mu \mathrm{g}$ IGFl $(100 \mu \mathrm{g} / \mathrm{mL}$ stock solution).

6. LDN193189: resuspend $5 \mathrm{mg} \mathrm{LDN} 193189$ in $2.09 \mathrm{~mL}$ nuclease-free sterile ultrapure water for a $5 \mathrm{mM}$ stock solution.

Matrigel hESC-qualified (Corning, reference 354277) is prepared as recommended by the manufacturer. For a $10 \mathrm{~cm}^{2}$ surface, use $1 \mathrm{~mL}$ of cold Matrigel diluted in DMEM/F12. Coating must be done at $4{ }^{\circ} \mathrm{C}$ and coated plates can be stored for 15 days at $4{ }^{\circ} \mathrm{C}$. Plates should be placed at room temperature or $37^{\circ} \mathrm{C}$ for at least $1 \mathrm{~h}$ before use. Placing plates at $37^{\circ} \mathrm{C}$ increases cell adhesion.

Prepare $5 \mathrm{~mL}$ of $100 \times$ penicillin-streptomycin $100 \times, 5 \mathrm{~mL}$ of $100 \times$ nonessential amino acids (NEAA), $5 \mathrm{~mL}$ of $100 \times$ GlutaMAX, $5 \mathrm{~mL}$ of $100 \times \mathrm{N} 2$ supplement (Thermofisher, reference 17502048 ), and $10 \mathrm{~mL}$ of $50 \times$ B27 supplement (Thermofisher, reference 0080085SA), and add Neurobasal medium (Thermofisher, reference 10888022 ) to a final volume of $500 \mathrm{~mL}$.

Use $10 \mathrm{~mL}$ of basal differentiation medium and add $100 \mu \mathrm{L}$ of $100 \times$ ITS-A, $1 \mu \mathrm{L}$ of $5 \mathrm{mM}$ LDN193189 solution $(0.5 \mu \mathrm{M}$ final concentration), $3 \mu \mathrm{L}$ of a $10 \mathrm{mM}$ CHIR99031 solution $(3 \mu \mathrm{M}$ final concentration), $2 \mu \mathrm{L}$ of a $100 \mu \mathrm{g} / \mathrm{mL}$ FGF2 solution $(20 \mathrm{ng} / \mathrm{mL}$ final concentration).

Use $10 \mathrm{~mL}$ of basal differentiation medium and add $0.4 \mu \mathrm{L}$ of a $100 \mu \mathrm{g} / \mathrm{mL}$ IGFl solution $(4 \mathrm{ng} / \mathrm{mL}), 1 \mu \mathrm{L}$ of a $10 \mu \mathrm{g} / \mathrm{mL}$ HGF solution $(10 \mathrm{ng} / \mathrm{mL}$ final concentration), $1 \mu \mathrm{L}$ of $5 \mathrm{mM}$ LDN193189 solution $(0.5 \mu \mathrm{M}$ final concentration), $2 \mu \mathrm{L}$ of a $100 \mu \mathrm{g} / \mathrm{mL}$ FGF2 solution $(20 \mathrm{ng} / \mathrm{mL}$ final concentration, $18.16 \mu \mathrm{L}$ of a $50 \mathrm{mM} \beta$-mercaptoethanol solution $(90.8 \mu \mathrm{M}$ final concentration).

Use $10 \mathrm{~mL}$ of basal differentiation medium and add $0.4 \mu \mathrm{L}$ of a $100 \mu \mathrm{g} / \mathrm{mL}$ IGFl solution $(4 \mathrm{ng} / \mathrm{mL}), 1 \mu \mathrm{L}$ of a $10 \mu \mathrm{g} / \mathrm{mL}$ HGF solution (10 ng/mL final concentration), $2 \mu \mathrm{L}$ of a $100 \mu \mathrm{g} / \mathrm{mL}$ FGF2 solution $(20 \mathrm{ng} / \mathrm{mL}$ final concentration), $18.16 \mu \mathrm{L}$ of a $50 \mathrm{mM} \beta$-mercaptoethanol solution $(90.8 \mu \mathrm{M}$ final concentration $)$. 
2.3.5 Differentiation

Medium Step 4

2.3.6 Differentiation Medium Step 5

2.4 Cell Freezing and Thawing
Use $10 \mathrm{~mL}$ of basal differentiation medium and add $0.4 \mu \mathrm{L}$ of a $100 \mu \mathrm{g} / \mathrm{mL}$ IGFl solution $(4 \mathrm{ng} / \mathrm{mL}), 18.16 \mu \mathrm{L}$ of a $50 \mathrm{mM}$ $\beta$-mercaptoethanol solution $(90.8 \mu \mathrm{M}$ final concentration).

Use $10 \mathrm{~mL}$ of basal differentiation medium and add $0.4 \mu \mathrm{L}$ of a $100 \mu \mathrm{g} / \mathrm{mL}$ IGFl solution $(4 \mathrm{ng} / \mathrm{mL}), 18.16 \mu \mathrm{L}$ of a $50 \mathrm{mM}$ $\beta$-mercaptoethanol solution ( $90.8 \mu \mathrm{M}$ final concentration $), 10 \mu \mathrm{L}$ of a $10 \mathrm{mM}$ DAPT solution (N-[(3,5-difluorophenyl)acetyl]-L-alanyl-2-phenyl]glycine 1,1-dimethylethyl ester; $10 \mu \mathrm{M}$ final concentration).

From Days 10 to 12 , cells can be frozen. Therefore, medium is removed and cells are rinsed in $1 \times$ PBS. Then $0.5-1 \mathrm{~mL}$ Accutase is added and cells are incubated for $3-5 \mathrm{~min}$ at $37^{\circ} \mathrm{C}$. Cells are then collected by gentle flushing in basal differentiation medium. Cells are then collected in a $15 \mathrm{~mL}$ tube and centrifuged for $5 \mathrm{~min}$ at $900 \mathrm{rpm}$. Cells are frozen in $1 \mathrm{~mL}$ of $90 \%$ SVF- $10 \%$ DMSO.

For thawing, cells are seeded in differentiation medium step 3 (Subheading 2.3.4). Cells are grown for $3-5$ days in this medium and then transferred to differentiation medium step 5 (Subheading 2.3.6). Thiazovivin can be added to the medium to increase cell survival.

Unless otherwise specified, procedures are carried out at room temperature. Cells are incubated at $37{ }^{\circ} \mathrm{C}$ with $5 \% \mathrm{CO}_{2}$. At each step, media must be warmed at room temperature $\left(15-25^{\circ} \mathrm{C}\right)$ prior to use.

1. From a full $35 \mathrm{~mm}$ dish, hiPSC colonies are mechanically disrupted using a 24-gauge needle into small clumps of cells. Each colony can be dissociated into eight to ten clumps (see Note 1).

2. Clumps are collected using a p200 tip and approximately 10-15 colonies (i.e., $80-120$ clumps or $100,000-150,000$ cells).

3. Clumps are plated on a new Matrigel-coated $35 \mathrm{~mm}$ dish in a chemically defined differentiation medium supplemented with FGF2, the LDN 193189 BMP pathway inhibitor and CHIR 9902l GS3K inhibitor, in the presence of thiazovivin, a Rock pathway inhibitor for $24 \mathrm{~h}$ (differentiation medium step l, Subheading 2.3.2; Fig. 2, D2-D4-D6).

4. Use 150,000 cells for a $35 \mathrm{~mm}^{2}$ dish or 2 well tissue culture chamber mounted on polycycloalkane (PCA) slides; 60,000 cells per well for 12-well plates or 30,000 cells per well for 24-well plates. 

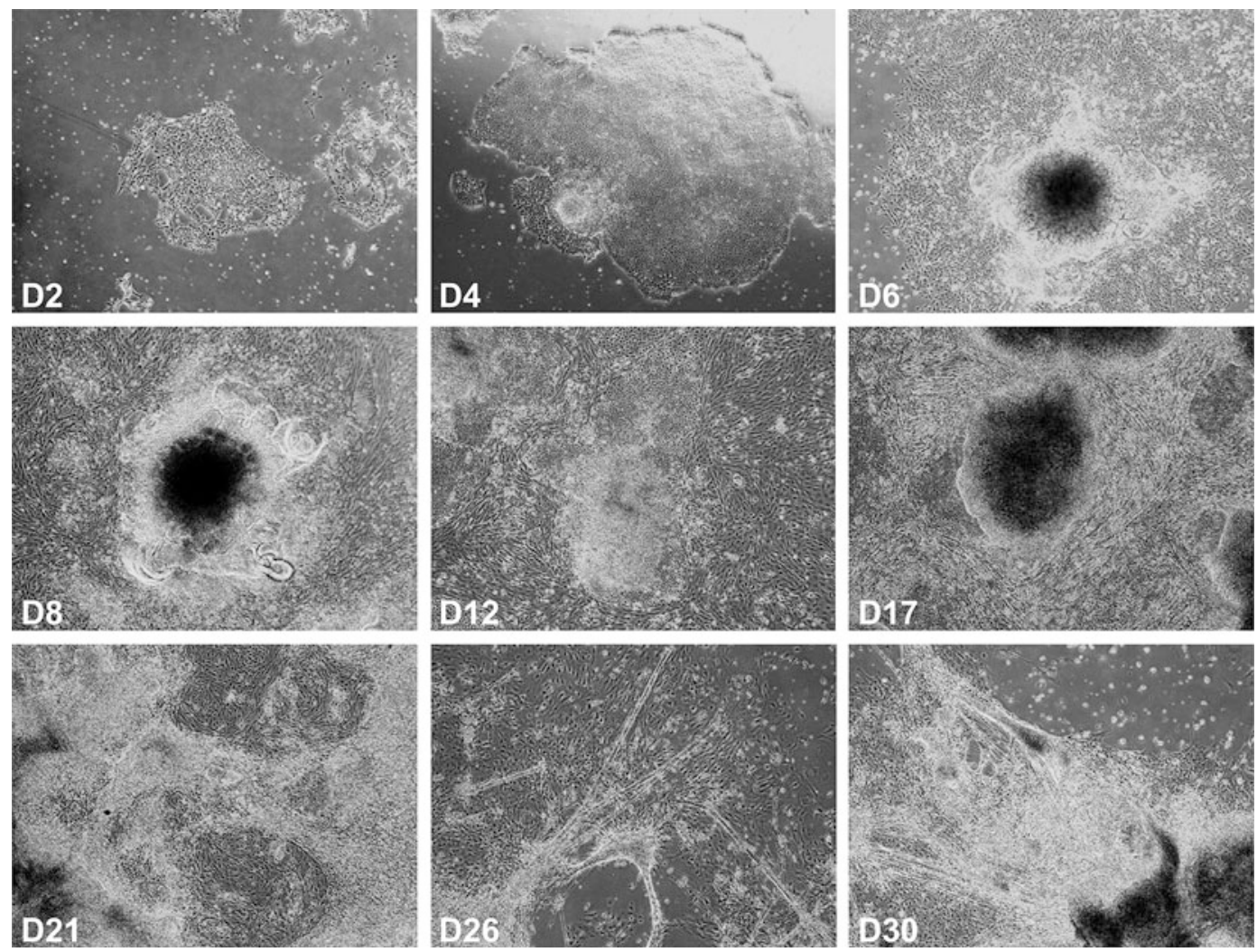

Fig. 2 Morphology of hiPSC-derived innervated muscle fibers. Phase contrast images of cells differentiated from human induced pluripotent stem cells (hiPSCs) at Day 2 (D0), D4, D6, D8, D12, D17, D21, D26, and D30 corresponding to the different changes in the composition of the medium

5. Cells are maintained for 6 days in this medium with daily medium change.

6. On the sixth day, cells are grown in differentiation medium step 2, supplemented with LDN 193189, Insulin Growth Factor 1 (IGFl) and Hepatocyte Growth Factor (HGF) for $48 \mathrm{~h}$ to favor muscle and neuron progenitor differentiation (Fig. 2, D6-D8).

7. HGF is then removed and cells are maintained in DM + IGFl (differentiation medium step 4, Subheading 2.3.5) for 4 more days (until day 12) during which cells proliferate. Alternatively, cells can be maintained in differentiation medium 3 between Days 8 and 11 to increase expansion of progenitors (see Note 2).

8. At Day 12 (D12, Fig. 2), DAPT, a $\gamma$-secretase and Notch pathway inhibitor is added to the medium to induce neuronal differentiation (differentiation medium step 5, Subheading 2.3.6). 
9. At Days 10-12 postdifferentiation, cells can be collected after dissociation with Accutase and cryopreserved for short-term storage at $-80^{\circ} \mathrm{C}$ or long-term storage in liquid nitrogen and thawed for further amplification and differentiation. Upon thawing, it is recommended to grow the cells in differentiation medium 4 (in the presence of FGF2, IFG1, and HGF) for 2-3 days prior to DAPT addition. Thiazovivin can be added upon thawing to increase cell survival (see Note $\mathbf{3}$ ).

10. Between Days 10 and 12, cells can be collected by dissociation with Accutase for freezing, storage, thawing, and replating.

11. Between days 10 and 12 , cells can be also amplified or transferred to different Matrigel-coated surfaces (such as culture plates or slides). Use 150,000 cells for a $35 \mathrm{~mm}^{2}$ dish or 2-well tissue culture chamber mounted on PCA slides; 50,000 cells per well for 96-well plates ( see Note 4).

12. From D17 onward, cells in differentiation medium step 4 (Subheading 2.3.5) form large patches of elongated contractile fibers clearly visible by bright field imaging (Fig. 2, D17, D21, D26, D30). First contractions become visible 2-4 days after the removal of DAPT (Days 19-20) (differentiation medium step 4, Subheading 2.3.5), with axons visible by bright field imaging (D17).

The same methodology can be applied to cells from healthy donors or patients affected with neuromuscular disorders, with a possible adaptation of cell culture conditions between days 8 and 12 (Fig. la).

At the different steps of differentiation, expression of muscle or neuronal markers can be monitored by flow cytometry, gene expression analysis, or immunostaining. For immunostaining, we recommend image acquisition by confocal microscopy as differentiated cells form different layers. We also successfully performed electron microscopy for ultrastructural analysis. Muscle contraction and electrical activity can be monitored allowing functional characterization and drug-response testing.

\section{Notes}

1. Each colony can be dissociated into eight to ten clumps.

2. Alternatively, cells can be maintained in differentiation medium 3 between Days 8 and 11 to increase expansion of progenitors.

3. Upon thawing, it is recommended to grow the cells in differentiation medium 4 (in the presence of FGF2, IFG1, and HGF) for 2-3 days prior to DAPT addition. Thiazovivin can be added upon thawing to increase cell survival. 
4. Use 150,000 cells for a $35 \mathrm{~mm}^{2}$ dish or 2-well tissue culture chamber mounted on PCA slides; 50,000 cells per well for 96-well plates.

\section{Acknowledgments}

This study was funded by Association Française contre les Myopathies (AFM, TRIM-RD program) and Region Provence Alpes Côte d'Azur (Cladimus project, 2018-06436). M.D. is the recipient of a fellowship from the French Ministry of Research and Higher Education. The project leading to this chapter has received funding from the Excellence Initiative of Aix-Marseille UniversityA*Midex, a French "investissement d'avenir programme" AMX-19-IET-007 through the Marseille Maladies Rares (MarMaRa) Institute. Mégane Delourme and Natacha Broucqsault contributed equally to this work.

\section{References}

1. Onder TT, Daley GQ (2012) New lessons learned from disease modeling with induced pluripotent stem cells. Curr Opin Genet Dev 22(5):500-508. https://doi.org/10.1016/j. gde.2012.05.005

2. Robinton DA, Daley GQ (2012) The promise of induced pluripotent stem cells in research and therapy. Nature 481(7381):295-305. https://doi.org/10.1038/nature10761

3. Inoue H, Nagata N, Kurokawa H, Yamanaka S (2014) iPS cells: a game changer for future medicine. EMBO J 33(5):409-417. https:// doi.org/10.1002/embj.201387098

4. Walmsley GG, Hyun J, McArdle A, SenarathYapa K, Hu MS, Chung MT et al (2014) Induced pluripotent stem cells in regenerative medicine and disease modeling. Curr Stem Cell Res Ther 9(2):73-81

5. Rohwedel J, Maltsev V, Bober E, Arnold HH, Hescheler J, Wobus AM (1994) Muscle cell differentiation of embryonic stem cells reflects myogenesis in vivo: developmentally regulated expression of myogenic determination genes and functional expression of ionic currents. Dev Biol 164(1):87-101. https://doi.org/ 10.1006/dbio.1994.1182

6. Wobus AM, Guan K, Yang HT, Boheler KR (2002) Embryonic stem cells as a model to study cardiac, skeletal muscle, and vascular smooth muscle cell differentiation. Methods Mol Biol 185:127-156
7. Kennedy KA, Porter T, Mehta V, Ryan SD, Price F, Peshdary V et al (2009) Retinoic acid enhances skeletal muscle progenitor formation and bypasses inhibition by bone morphogenetic protein 4 but not dominant negative beta-catenin. BMC Biol 7:67. https://doi. org/10.1186/1741-7007-7-67

8. Zheng JK, Wang Y, Karandikar A, Wang Q, Gai H, Liu AL et al (2006) Skeletal myogenesis by human embryonic stem cells. Cell Res 16 (8):713-722. https://doi.org/10.1038/sj.cr. 7310080

9. Darabi R, Gehlbach K, Bachoo RM, Kamath S, Osawa M, Kamm KE et al (2008) Functional skeletal muscle regeneration from differentiating embryonic stem cells. Nat Med 14 (2):134-143. https://doi.org/10.1038/ $\mathrm{nm} 1705$

10. Chal J, Oginuma M, Al Tanoury Z, Gobert B, Sumara O, Hick A et al (2015) Differentiation of pluripotent stem cells to muscle fiber to model Duchenne muscular dystrophy. Nat Biotechnol 33(9):962-969. https://doi.org/10. $1038 /$ nbt.3297

11. Xi H, Fujiwara W, Gonzalez K, Jan M, Liebscher S, Van Handel B et al (2017) In vivo human somitogenesis guides somite development from hPSCs. Cell Rep 18 (6):1573-1585. https://doi.org/10.1016/j. celrep.2017.01.040 
12. Choi IY, Lim H, Estrellas K, Mula J, Cohen TV, Zhang Y et al (2016) Concordant but varied phenotypes among duchenne muscular dystrophy patient-specific myoblasts derived using a human iPSC-based model. Cell Rep 15(10):2301-2312. https://doi.org/10. 1016/j.celrep.2016.05.016
13. Mayeuf-Louchart A, Lagha M, Danckaert A, Rocancourt D, Relaix F, Vincent SD et al (2014) Notch regulation of myogenic versus endothelial fates of cells that migrate from the somite to the limb. Proc Natl Acad Sci U S A $111(24): 8844-8849 . \quad$ https://doi.org/10. $1073 /$ pnas.1407606111 